\title{
Factors impacting university-industry collaboration in European countries
}

\author{
Bojan Ćudić ${ }^{*} \mathbb{D}$, Peter Alešnik and David Hazemali
}

\section{*Correspondence:}

bojan.cudic@um.si University of Maribor,

Maribor, Slovenia

\begin{abstract}
This paper aims to examine the links between university-industry collaboration (UIC) predictors (inputs) and the results of UIC cooperation (outputs). The focus of the research is UIC within the European Union member states and the Western Balkan countries. The analysis was conducted using the partial least squares structural equation modeling (PLS-SEM). This method enabled examining the links between variables that are not directly observable. The authors used data for the period of three years, 2015-2018. The results prove that countries investing in UIC predictors (inputs) have better UIC performance (outputs). Based on the statistical analysis, the authors identified the investments in knowledge, networking, and research and development (R\&D), in general, as the most significant that impact UIC performance.
\end{abstract}

Keywords: University-industry collaboration, Europe, knowledge, Networking, R\&D, PLS-SEM

\section{Introduction}

In recent decades, researchers have been intrigued by the ever-increasing importance of university-industry collaboration (UIC), in particular by the factors of its success (Hillebrand \& Biemans, 2003; Parkhe, 1993). UIC is emerging as a critical component of the innovation process. It is a vital component of the regional innovation policy-mix for regional policymakers as the successful exploitation of R\&D results is fundamental for regional competitiveness (Morisson \& Pattinson, 2020).

A noticeable shift towards regionalization in innovation policy and technology is evident. One of its consequences is the expectation for universities to draft networks and establish regional ties (Koschatzky \& Stahlecker, 2010). Also of considerable importance is the construction of broad collaborative cluster networks, although most clusters focus on loosely defined local level networks. Notwithstanding, network members are responsible for more patent applications than others. What is more, there seems to be no loss of patent quality when collaborating with same cluster region universities (Nishimura \& Okamuro, 2010).

The authors emphasize the impact of co-patenting and co-publishing on the UIC and the importance of technological specialization. The analysis of co-patent data enhances the understanding of transnational knowledge flows, especially when used in

(c) The Author(s) 2022. Open Access This article is licensed under a Creative Commons Attribution 4.0 International License, which permits use, sharing, adaptation, distribution and reproduction in any medium or format, as long as you give appropriate credit to the original author(s) and the source, provide a link to the Creative Commons licence, and indicate if changes were made. The images or other third party material in this article are included in the article's Creative Commons licence, unless indicated otherwise in a credit line to the material. If material is not included in the article's Creative Commons licence and your intended use is not permitted by statutory regulation or exceeds the permitted use, you will need to obtain permission directly from the copyright holder. To view a copy of this licence, visit http:// creativecommons.org/licenses/by/4.0/. 
combination with the interpretation of co-patent statistics. The share of co-published research has increased since the 1990s, especially in European countries. As a result, smaller countries tend to collaborate more often, and the new European Union (EU) member states make up a larger portion of co-publishing activities. Lata et al. (2018) find that knowledge distance plays by far a larger role than technological distance for co-publication activities. Links between distant regions in Europe are less likely than in the United States of America (USA). However, being neighbors matters more in the USA than in Europe. This counterbalances the geographical effect for regions that are not too far away from each other. When examining patents, authors notice that the USA, Japan, Canada and Western Europe (G4) countries host the large majority of international teams, almost $80 \%$, followed by the combination G4-the rest of the world. But the two groups follow different trends, and G4-the rest of the world collaborations almost catch up with intra-G4 ones by the turn of the century (Miguelez et al., 2019).

UIC is mostly based on knowledge and technology transfer. Philbin (2010) notes that there is much evidence for a strong correlation between technology transfer and practical knowledge on the one side, and successful collaboration on the other. An intense transfer can improve the technology novelty (Guan et al., 2005), encourage innovation performance (MingJi \& Ping, 2014), and/or boost product development (Fernandes \& Ferreira, 2013). Nevertheless, many barriers impact knowledge and technology transfer, and this is a topic of many pieces of research (see de Medeiros et al., 2012; Hong et al., 2010; Schofield, 2013). In their study from 2009, Flores et al. state that technology transfer and knowledge are influenced by strategy and motivation (Flores et al., 2009), where utilization of adequate policies and incentives can enhance transfer activities in UIC (Schofield, 2013). Knowledge transfers might be impacted differently by universities and companies. While the former initiate knowledge transfer through research, the latter take on more managerial positions afterward (Goel et al., 2017).

There are multiple motives for UIC, which often meet many barriers. In their study, Muscio and Vallanti (2014) identified the following obstacles in the UIC: Misalignment of incentives between researchers and firms (conflicts with companies); Lack of academic procedures or intermediaries to ease the interaction with businesses (academic networking problems); Misalignment between academic goals and technological transfer activity (conflicts with academic goals), and distance between academic research and business needs (nature of research). Financial obstacles are shown to be strongly related to the propensity of knowledge-intensive business services to collaborate with universities and research institutes (URIs). Knowledge obstacles are moderately related to the propensity of high-tech manufacturing SMEs to collaborate with URIs. Silva et al. (2019) conclude that while URIs have other important roles in the techno-economic system, their perceived contribution to alleviating internal innovation barriers for technologybased SMEs may be less prominent than policy decision-makers in emerging economies may expect.

To investigate factors that impact UIC, the authors used data provided by the Global Innovation Index (GII). The Innovation Input Sub-Index and the Innovation Output Sub-Index-each constructed around pillars, are two sub-indices the GII relies on. In the Innovation Input Sub-Index, elements of the national economy that enable innovative activities are captured by five input pillars. The five input pillars are business 
sophistication, market sophistication, infrastructure, human capital and research, and institutions. The Innovation Output Sub-Index encompasses innovation outputs, which stem from innovative activities within the economy. The output pillars are creative outputs, and knowledge and technology outputs. The average of the Input and Output subindices marks the overall GII score (Cornell University, INSEAD, \& WIPO, 2010-2020).

Based on the defined elements, the authors created groups of factors that influence UIC (impact factors). On the other hand, the UIC performance level in a specific country is measured by the set of output factors. The differences in approach to the support of UIC also lead to companies achieving different results. This motivated the authors to explore the main factors that impact UIC in European countries. Thus, this research intends to answer the following question: "What are the vital factors that influence UIC"?

\section{Literature review}

Many articles deal with the factors that make UIC successful. Rybnicek and Königsgruber (2019) conducted a thorough, in-depth review of the published scholarly literature on industry-university collaboration. They performed an extensive analysis of UIC projects' research to distil factors that influence such partnerships' success. Given the comprehensiveness of this research, as the authors of this paper used it as a base for identifying factors that determine UIC. Many other authors also deal with this topic, and the most recent and relevant articles are presented in this part of the research.

Based on the review of the existing literature, the authors could organize the factors that determine UIC. They are marked as "input factors" in the research and deployed into four categories. Firstly, there are institutional factors, which refer to business environment and government effectiveness. Secondly, there are human factors, which refer to human capital and research. Thirdly, there are linkage factors, which refer to relationships between universities and companies. Fourthly, there are framework factors, which refer to the business infrastructure. Finally, the authors define "output factors" that presents the level of UIC in a specific country.

\section{Institutional factors}

Institutional factors include the business environment, legal restrictions, and/or governmental support. Kozlinska (2012) defines the government as an influential power with the ability to either facilitate or harm collaboration. On the one hand, the governmental network (Rampersad, 2015), public funding (e.g., Flores et al., 2009; Piva \& RossiLamastra, 2013), or tax incentives (Bodas Freitas et al., 2013) can facilitate UIC. On the other hand, the absence of regional bracing structures (Şerbănică, 2011), and/or regulations and legal restrictions (Arvanitis et al., 2008; Attia, 2015; Hadjimanolis, 2006) can have a negative impact on collaboration. As a rule, industry-university partnerships rely heavily on governmental support (e.g., Collier et al., 2011; de Medeiros et al., 2012; Hemmert et al., 2014; Muscio \& Vallanti, 2014; Myoken, 2013; Newberg \& Dunn, 2002; Schofield, 2013; Sohal, 2013). Additional factors of business environmental success correspond to the market potential of research results (Ankrah \& AL-Tabbaa, 2015; Barnes et al., 2002; Guan et al., 2005; Hadjimanolis, 2006) or market uncertainties (Hemmert et al., 2014). 


\section{Human factors}

Human resources play a vital role in the successful implementation of university-industry projects (Albats et al., 2020). Normally, there exists a strong dependence of the utility and quality of collaboration on the partner's available resources. The need for specific resources further limits the scope of potential partners (Ferru, 2010). For successful collaboration, highly qualified human resources (Myoken, 2013) are paramount. Also, of significance are unrestricted access to libraries, lab space, and similar infrastructure (Boardman \& Bozeman, 2015); and/or technical equipment (Arvanitis et al., 2008). Companies with better-educated and/or more knowledgeable managers/supervisors tend to innovate more (Marotta et al., 2007). In his analysis of a survey of 39,336 enterprises, Merrit (2015) argues that larger enterprises due to a higher level of human capital can harness university-driven and generated knowledge more efficiently than smaller enterprises. The latter are less capable of absorbing said knowledge since they generally lack qualified technicians and engineers who are invaluable for innovation endeavors.

\section{Linkage factors}

In the research, linkage factors refer to gross domestic expenditure on R\&D (GERD) performed by an enterprise, GERD financed by a business enterprise, university-industry research collaboration, the state of cluster development, GERD financed from abroad, and by joint venture/strategic alliance deals. Working together and implementing each other's experience and feedback in the pursuit of improvements has been proven beneficial for both universities and companies (Ryan, 2009). Albats et al. (2020) argue that the preeminent aspect of a company's strategy in the shaping of their innovation performance is the creation of strategic partnerships, in particular university partnerships. The impact of communication is thoroughly examined in the addressed literature. The authors ought to emphasize that to establish a shared understanding, communication frequency is paramount (Hong et al., 2010; Lee, 2011). Close personal relationships also enable crucial links between universities and companies (Barnes et al., 2002; Collier et al., 2011). Contacts and actions ought to be on the operational level (regular interaction, mutual exchange of information with continuous feedback, and updating partners on new activities or incidents) and encompass the management level (Wu, 2017). Guan et al. regard the absence of communication channels as the primary barrier in partnerships (Guan et al., 2005). Also beneficial for the establishment of positive expectations about the partner's future behavior (especially when the partnership is still fresh) is reciprocal communication (accurate, adequate, timely, and regular) (Bstieler et al., 2017). Finally, The authors considered the role of culture in UICs. The latter is defined as the mutual understanding within a company on how employees ought to view, feel and think about issues and challenges (Schein, 2004).

\section{Framework factors}

In the research, the framework factors refer to ICT access, ICT use, electricity output, logistics performance, gross capital formation, environmental performance, and the rule of law. Nishimura and Okamuro (2010) explained that UIC's legal aspects and intellectual property rights (IPRs) are significant. The IPR policy of governments and universities has a positive and significant impact on UIC project performances, controlling 
for firm and project characteristics and considering potential selection bias from UIC participation. Betz et al. (2010) state that a favorable business environment does not, by default, affect the university's technology transfer activities positively. It is the implemented strategy of each university that is much more important than the environmental factors. Nevertheless, with an overall improvement in R\&D capability, R\&D collaboration, and technology, commercialization will also be enhanced (Vea, 2014).

The results demonstrate that increased attention to technology R\&D and the protection of patents by governments and companies has led to immense improvements in the ICT sector. What is more, companies have now become the main body of technological innovation (Xia et al., 2014). Yarmouk University has developed dynamic programs of ICT enrichment and adopted an innovative partnership model, which in the form of an on-campus facility seeks to bridge the academia-industry gap. The facility offers a productive, internal collaborative environment for technical and business faculties, which together pursue projects to cultivate collaboration with industrial and business partners. Moreover, it facilitates the alignment of skills and knowledge of university staff and students to contemporary real industry needs, and updates the university's knowledge base with the latest industry developments (Al-Agtash \& Al-Fahoum, 2008).

\section{Output factors}

In the literature, there are many performance indicators of UIC. The number of patents (Xia et al., 2014), scientific and technical articles (Salimi \& Rezaei, 2016), high-tech manufactures and exports (Aiello et al., 2019), intellectual property receipts (Valentin \& Jensen, 2007), ICT services exports (D'Costa, 2006; Hwang, 2020), cultural and creative services exports (Draghici et al., 2016), creative goods exports (Banal-Estañol et al., 2011), are frequently mentioned. In general, the output indicators can be divided into two groups: tangible and intangible.

As Rybnicek and Königsgruber (2019) stated, the compatibility of partner-to-partner goals is among the most discussed subjects in UICI literature. Failure to achieve the desired outcome is often the result of incompatibility (Henderson et al., 2006). For example, companies strive towards withholding the groundbreaking findings from universities from competitors, while the universities desire to publish them (Newberg \& Dunn, 2002). Lai and Lu provide similar results Lai and Lu (2016). They state that companies and universities strive towards different goals. Consequently, it is paramount to seek a win-win situation with balanced benefits for both partners. This can be achieved only if both partners understand the other's interests. Also essential is for partners to agree upon achievable goals through a shared understanding of the objectives, and to materialize a precise strategy throughout the collaboration (Hong et al., 2010). It should also be added that partners more often than not hold unrealistic expectations about the outcome of cooperation, and/or have a different sense of urgency (Attia, 2015).

For the purpose of finding the appropriate partner, a correct partner selection process is advised prior to collaboration. In this sense, confidence in one's own needs and requirements is also a prerequisite. Only then can the search for an adequate partner with concordant interests and goals begin (Arvanitis et al., 2008). Adequate search strategies can facilitate the search for a matching partner. Barnes et al. (2002) recommend a partner evaluation method with specific criteria. 


\section{Methodology}

\section{Construct measures}

The authors have grounded the theoretical framework of this research in a systematic review of relevant scholarly literature while also considering the availability of the variables' data. At the outset, the authors elicited 36 measures. These were grouped into six constructs, four of which focus on input factors, the remaining two on output factors (Table 1). The authors depicted the research model in Fig. 1.

Figure 1 depicts the model' schematic diagram. Both the internal and external relationships were considered. ${ }^{1}$ The estimation was conducted with the help of SmartPLS software.

\section{Research method}

This research uses the structural equation modeling method (SEM). SEM encompasses a plethora of statistical methodologies by which a causal relationship's network can be approximated. A theoretical model defines such a network as one which links at least two latent complex concepts. Several observable indicators measure each of these concepts. In essence, it can study the complexity within a system by considering a causality network among latent concepts- "latent variables". Many observed indicators usually defined as "manifest variables" are used to measure each of these latent variables. According to this, structural equation models represent a joint-point between path analysis and confirmatory factor analysis (Esposito Vinzi et al., 2010). Among the methods of estimating SEM models, the covariance-based (CB) method, ${ }^{2}$ invented by K. G. Jöreskog, enjoyed the greatest popularity for a long time. So universal was its recognition that in social sciences the phrases: SEM and covariance-based structural equation modeling (CB-SEM) were synonymous for many years (Chin et al., 1996). Meanwhile, $\mathrm{H}$. Wold developed an alternative approach-the partial least square method (PLS). Its description and application for estimating models with latent variables were presented by Wold in, among others: (Wold, 1980a, 1980b, 1982). Because the PLS method was an alternative to K. G. Jöreskog's 'hard' modelling, i.e. one based on strong assumptions regarding the normality of distributions and requiring large samples, Wold referred to his PLS approach as 'soft' modelling (Wold, 1980b, 1982). After a time, the term 'PLSpath modelling. ${ }^{3}$ Came into use, and then-in order to emphasize that PLS was an alternative to CB, it began to be called 'PLS Structural Equation Modeling' (PLS-SEM).

PLS-SEM and CB-SEM were developed as distinct, though complementary, methods with specific purposes and requirements. This was clearly stressed by the authors of both approaches at the beginning of the 1980s (Jöreskog \& Wold, 1982). At present, the varying properties of PLS-SEM and CB-SEM are also noticed, with emphasis on the complementarity of the two methods instead of the competition between them. The advantages of the non-parameter, variance-based PLS-SEM modelling are, at the

\footnotetext{
${ }^{1}$ Internal model relationships are represented by the solid line, while the broken line was used for the external model relationships.

${ }^{2}$ In the CB-SEM method, a theoretical covariance matrix is estimated on the basis of a structural equations model. The estimation of model parameters is performed in such a way as to minimize the difference between the theoretical covariance matrix and the estimated covariance matrix.

3 Among other things, in order to distinguish models containing latent variables estimated by means of the PLS method from PLS-based regression. Even now, in many publications, authors confuse the work of H. Wold and that of S. Wold.
} 
Table 1 Factor measures and data source

\begin{tabular}{|c|c|c|c|}
\hline Construct & Measure & Code & Data source \\
\hline \multirow[t]{7}{*}{ Institutional factors } & & IIF & World Intellectual Property Organization \\
\hline & Political and operational stability & $\| F 1$ & (WIPO), 2015-2018 \\
\hline & Government effectiveness & IIF2 & \\
\hline & Regulatory quality & IIF3 & \\
\hline & Ease of starting a business & IIF4 & \\
\hline & Gross expenditure on R\&D (GERD) & IIF5 & \\
\hline & Expenditure on education & IIF6 & \\
\hline \multirow[t]{7}{*}{ Human factors } & & $\mathrm{HF}$ & \\
\hline & PISA scales in reading, math, \& science & IHF1 & \\
\hline & Graduates in science \& engineering & $\mathrm{HHF} 2$ & \\
\hline & Tertiary level inbound mobility & IHF3 & \\
\hline & $\begin{array}{l}\text { Researchers, full-time equivalent } \\
\text { / Million population }\end{array}$ & IHF4 & \\
\hline & $\begin{array}{l}\text { Employment in knowledge-intensive } \\
\text { services }\end{array}$ & IHF5 & \\
\hline & Research talent in business enterprise & IHF6 & \\
\hline \multirow[t]{6}{*}{ Linkage factors } & & ILF & \\
\hline & GERD performed by business enterprise & ILF1 & \\
\hline & GERD financed by business enterprise & ILF2 & \\
\hline & $\begin{array}{l}\text { University-industry research collabora- } \\
\text { tion }\end{array}$ & ILF3 & \\
\hline & State of cluster development & ILF4 & \\
\hline & Joint venture/strategic alliance deals & ILF5 & \\
\hline \multirow[t]{8}{*}{ Framework factors } & & IFF & \\
\hline & ICT access & IFF1 & \\
\hline & ICT use & IFF2 & \\
\hline & Electricity output, kWh/mn pop & IFF3 & \\
\hline & Logistics performance & IFF4 & \\
\hline & Gross capital formation & IFF5 & \\
\hline & Environmental performance & IFF6 & \\
\hline & The rule of law & IFF7 & \\
\hline \multirow[t]{7}{*}{ Output intangible indicators } & & Oll & \\
\hline & Patent applications by origin & OII1 & \\
\hline & $\begin{array}{l}\text { Patent Cooperation Treaty (PCT) } \\
\text { international applications by origin }\end{array}$ & OII2 & \\
\hline & Scientific and technical publications & Oll3 & \\
\hline & $\begin{array}{l}\text { Trademark application class count by } \\
\text { origin }\end{array}$ & Oll4 & \\
\hline & Industrial designs by origin & Oll5 & \\
\hline & ICTs and business model creation & Oll6 & \\
\hline \multirow[t]{6}{*}{ Output tangible indicators } & & OTI & \\
\hline & Cultural and creative services exports & OTI1 & \\
\hline & Creative goods exports & OTI2 & \\
\hline & $\begin{array}{l}\text { The growth rate of Gross domestic prod- } \\
\text { uct (GDP) per person engaged }\end{array}$ & OTI3 & \\
\hline & $\begin{array}{l}\text { High-tech and medium high-tech } \\
\text { output }\end{array}$ & OTI4 & \\
\hline & New business density & OTI5 & \\
\hline
\end{tabular}

same time, the disadvantages of the parameter, covariance-based CB-SEM-and the other way around. Therefore, the choice of method should depend on the empirical context and research purposes (Hair et al., 2019).

An SEM model consists of two sub-models: a structural one and a measurement one. In PLS-SEM terminology, the phrases' inner model' and 'outer model', 
respectively, are also used. A structural model describes the relationships among latent variables, whereas a measurement model-the relationships among the latent variables and the indicators by which they are identified, also known as manifested variables (Wold, 1980a).

When constructing a structural model, one must pay particular attention to two aspects: the nature of the analyzed latent variables and the associations which occur among them. It is important to distinguish between exogenous variables and endogenous ones. Furthermore, all the formulated elements of the conceptual framework should be derived from theory and logic. If a theoretical basis is lacking, or if the theory is inconsistent, one should rely on one's own judgment, experience, and intuition (Hair et al., 2017).

Specification of the measurement model is an equally important stage of the modeling process. Verification of the hypotheses reflected in the structural model's equations can be reliable when, and only when, the latent variables are correctly defined by means of indicators. And the choice of indicators is as crucial as the choice of the way in which they are defined (Hair et al., 2017). Definition of latent variables by means of indicators can be done either deductively or inductively (Rogowski, 1990). Under the former approach, indicators reflect the defined latent variable and are then referred to as reflective indicators, while the measurement model is called a reflective measurement model. In the case of inductive definition, it is assumed that indicators make up the latent variables, hence the expressions formative indicators and formative measurement model. The type of definition (inductive or deductive) should follow from the assumed theoretical description (Rogowski, 1990). Also, the choice of observable indicators should be preceded by an in-depth and thorough literature review, including the theory and empirical studies in measuring the latent variables present in the model.

Alongside examining latent variables' correlations, PLS-SEM modeling also helps approximate the values of said variables (weighted sums of indicators). For that reason, a synthetic measurement, with which we can obtain a linear ordering of the studied objects, is calculated for each of the model's latent variables.

Estimation of a PLS-SEM model is performed using the PLS method. The algorithm simultaneously estimates inner model parameters-path coefficients-and outer model parameters-outer weights and outer loadings. The procedure also yields estimations of the values of all the latent variables included in the model. The estimation aims to maximize the explained variance of the latent dependent variables. The first stage involves the iterative estimation of measurement model weights and the values of latent variables. At the second stage, the loadings and path coefficients of the structural model are estimated. A detailed description of the PLS algorithm can be found, e.g., in Henseler et al. (2012) and Wold (1982), and its generalization in (Rogowski, 1990).

Verification of a PLS-SEM model is a two-stage process. First, the structural model is assessed. Second, if the validity of the structural model has been confirmed, the structural model is tested. Table 2 lists the properties of the model, which should undergo evaluation.

SEM using the PLS procedure used to be difficult due to the unavailability of software. Now the situation has greatly improved thanks to the wide range of user-friendly 


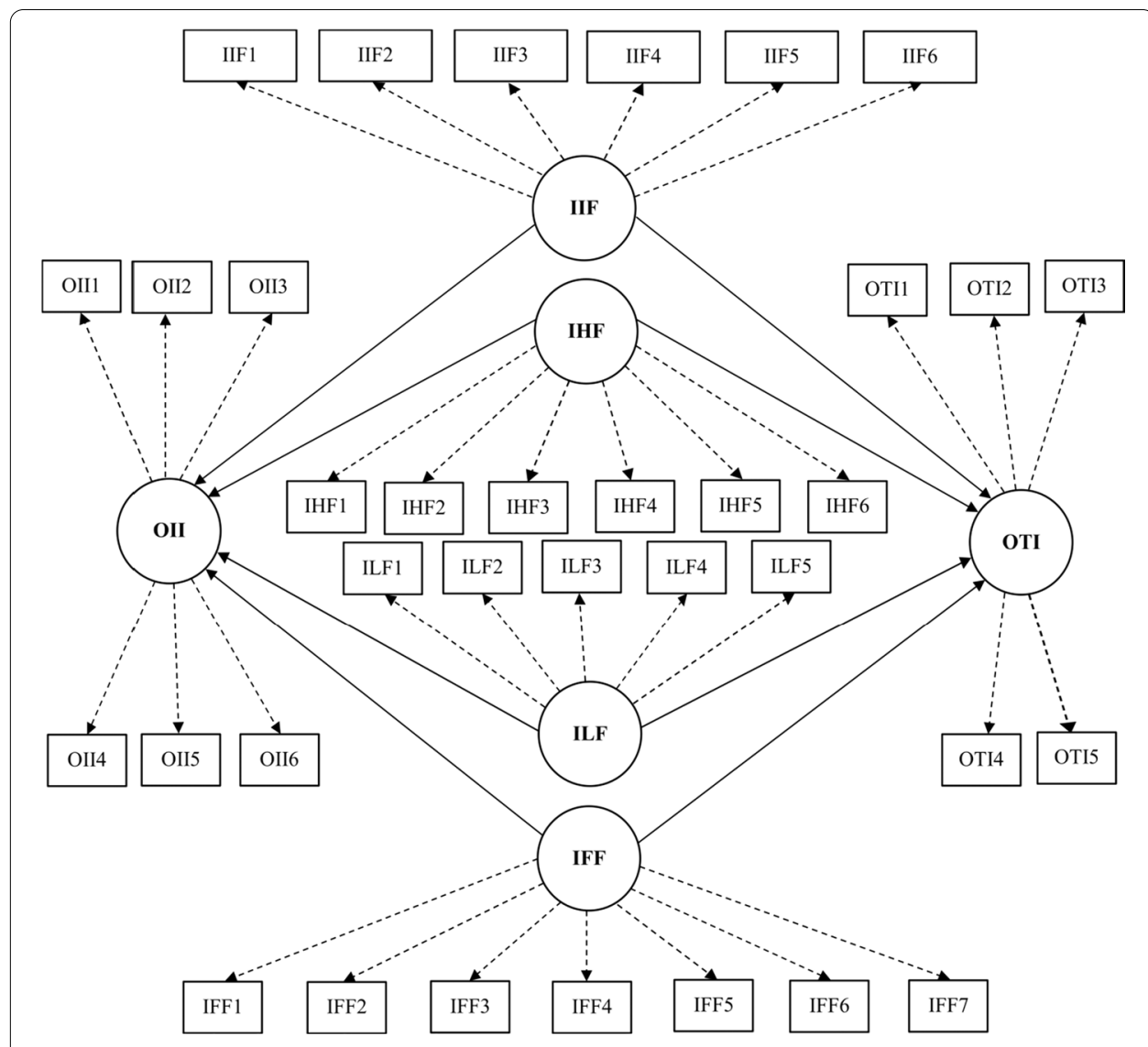

Fig. 1 Schematic diagram of internal and external relationships of the model

programs, which enable estimation and statistical verification of PLS-SEM models, e.g. WarpPLS (Kock, 2020), ADANCO (Henseler \& Dijkstra, 2015), SmartPLS (Ringle et al., 2015). This study will use the SmartPLS software.

\section{Specification of the model}

The model used for the realization of the research objective, i.e., proving the influence of UIC predictors on UIC performance, contains Eqs. 1a and 1b.

$$
\begin{aligned}
& \mathrm{OTI}_{\mathrm{t}}=\alpha_{1} \mathrm{IIF}_{\mathrm{t}+} \alpha_{1} \mathrm{IHF}_{\mathrm{t}}+\alpha_{1} \mathrm{ILF}_{\mathrm{t}+} \alpha_{1} \mathrm{IFF}_{\mathrm{t}+} \alpha_{0}+v_{\mathrm{t}} \\
& \mathrm{OII}_{\mathrm{t}}=\alpha_{1} \mathrm{IIF}_{\mathrm{t}+} \alpha_{1} \mathrm{IHF}_{\mathrm{t}}+\alpha_{1} \mathrm{ILF}_{\mathrm{t}+} \alpha_{1} \mathrm{IFF}_{\mathrm{t}+} \alpha_{0}+v_{\mathrm{t}}
\end{aligned}
$$

where:

$\mathrm{OTI}_{\mathrm{t}}-$ output tangible indicators in period $t$,

$\mathrm{OII}_{\mathrm{t}}-$ output intangible indicators in period $t$,

$\mathrm{IIF}_{\mathrm{t}}$-institutional factors in period $t$.

$\mathrm{IHF}_{\mathrm{t}}$-human factors in period $t$.

$\mathrm{ILF}_{\mathrm{t}}$-linkage factors in period $t$.

$\mathrm{IFF}_{\mathrm{t}}-$ framework factors in period $t$.

$\alpha_{0}, \alpha_{1}$-structural parameters of the model, 
$v_{t}$-random component,

$t$-Period of three years $2015-2018 .^{4}$

The authors used the deductive approach to defining latent variables in the model, i.e., each latent variable as a theoretical notion is a starting point for the search for empirical data. The indicators were selected based on substantive and statistical criteria. The following things were accounted for from the statistical perspective: indicator values' diversity, measured by the coefficient of variation ${ }^{5}$ (the coefficient's critical value was calculated at 10\%), and the quality of the estimated model (model evaluation measuresex-post analysis). Table 3 presents the indicators that passed substantive and statistical verification. The indicators of the input latent variables point to the most frequent and significant predictors of the UIC. Meanwhile, the OTI and OII measures reflect the outputs of UIC.

\section{Estimation results and statistical verification of the model}

Figure 2 shows the PLS-SEM estimation results obtained in the SmartPLS software (Ringle et al., 2015). The results are interpreted in section "Results and Discussion".

Table 4 contains the results of the estimation of the outer sub model.

Individual indicator reliability values significantly larger than the lowest acceptable level of 0.4 can be observed (Hulland, 1999).

Cronbach's alpha and composite reliability are shown to be larger than 0.6 , which means that high levels of internal consistency reliability have been demonstrated among the latent variables.

In order to confirm convergent validity, the average variance extracted (AVE) is evaluated for each latent variable. Table 4 also shows that the AVE values are greater than the acceptable threshold of 0.5 , which confirms convergent validity.

As suggested by Fornell and Larcker (1981), if this value exceeds other latent variables' correlation values, it can used the square root of AVE in each latent variable to establish discriminant validity.

The latent variable OII's AVE is found to be 0.944 (from Table 4) hence its square root becomes 0.920 (Table 5). The result indicates that discriminant validity is well established.

Using a two-tailed t-test with a significance level of 5\%, the path coefficient will be significant if the T-statistics is larger than 1.96. As presented in Table 6 all path coefficients in the inner model are statistically significant.

The values of the Stone-Geisser test statistic, which verifies the model in terms of its predictive usefulness (see Table 7), are positive, which proves the model's high predictive quality.

Both the measurement models and the structural models were positively assessed, therefore, in the next stage of modeling, the results can be interpreted.

\footnotetext{
${ }^{4}$ The Program for International Student Assessment (PISA) results is one of the significant indicators in the model. The PISA test was conducted across OECD countries in 2015 and 2018, and that is the reason why the authors chose these two years to examine changes in variables.

5 This is calculated as a ratio of the standard deviation to the arithmetic mean, expressed in percentage.
} 
Table 2 Evaluation of PLS-SEM models

\begin{tabular}{|c|c|c|c|c|c|}
\hline \multicolumn{6}{|c|}{ Evaluation of the measurement models } \\
\hline \multicolumn{3}{|c|}{ Reflective measurement models } & \multicolumn{3}{|c|}{ Formative measurement models } \\
\hline \multirow{2}{*}{$\begin{array}{l}\text { Internal consist- } \\
\text { ency }\end{array}$} & Cronbach's alpha & $0.60-0.95$ & \multirow{2}{*}{$\begin{array}{l}\text { Convergent } \\
\text { validity }\end{array}$} & \multirow{2}{*}{$\begin{array}{l}\text { Redundancy } \\
\text { analysis }\end{array}$} & \multirow{2}{*}{$\geq 0.7$ correlation } \\
\hline & $\begin{array}{l}\text { Composite reli- } \\
\text { ability }\end{array}$ & $0.60-0.95$ & & & \\
\hline \multirow{2}{*}{$\begin{array}{l}\text { Convergent } \\
\text { validity }\end{array}$} & Loadings & $\geq 0.7$ & \multirow{2}{*}{$\begin{array}{l}\text { Collinearity } \\
\text { between indica- } \\
\text { tors }\end{array}$} & \multirow{2}{*}{$\begin{array}{l}\text { Variance Inflation } \\
\text { Factor (VIF) }\end{array}$} & \multirow[t]{2}{*}{$\geq 0.5$} \\
\hline & $\begin{array}{l}\text { The average } \\
\text { variance extracted } \\
\text { (AVE) }\end{array}$ & $\geq 0.5$ & & & \\
\hline \multirow{3}{*}{$\begin{array}{l}\text { Discriminant } \\
\text { validity }\end{array}$} & Cross-loadings & & \multirow{3}{*}{$\begin{array}{l}\text { Significance of } \\
\text { outer weights }\end{array}$} & \multirow[t]{3}{*}{$p$-value } & \multirow[t]{3}{*}{$<0.05$} \\
\hline & \multicolumn{2}{|c|}{ Fornell-Larcker criterion } & & & \\
\hline & $\begin{array}{l}\text { Heterotrait- } \\
\text { monotrait ratio } \\
\text { (HTMT) }\end{array}$ & $<0.9$ & & & \\
\hline \multicolumn{6}{|c|}{ Evaluation of the structural models } \\
\hline \multicolumn{2}{|l|}{ Collinearity } & \multicolumn{2}{|l|}{ VIF } & \multicolumn{2}{|l|}{$\geq 0.5$} \\
\hline \multicolumn{2}{|l|}{ Predictive power } & \multicolumn{2}{|c|}{$\begin{array}{l}\text { Coefficients of determi- } \\
\text { nations }\left(R^{2}\right)\end{array}$} & \multicolumn{2}{|c|}{$\begin{array}{l}\text { values of } 0.75,0.50 \text { and } 0.25 \text { are } \\
\text { considered substantial, moderate, } \\
\text { and weak }\end{array}$} \\
\hline \multicolumn{2}{|c|}{ Predictive relevance } & \multicolumn{2}{|c|}{ Stone-Geisser's $Q^{2}$ value } & \multicolumn{2}{|l|}{$\geq 0$} \\
\hline \multicolumn{2}{|c|}{ Significance of path coefficients } & \multicolumn{2}{|c|}{$p$-value } & \multicolumn{2}{|l|}{$<0.05$} \\
\hline
\end{tabular}

Source: authors' work based on Hair et al. (2017)

\section{Results}

Figure 3a-e present the ordering of the indicators of each of the latent variables in terms of values of outer loadings, i.e., in terms of the strength of the relationship between the values of the latent variable and the values of the indicators.

The following interpretation of the $\pi i j$ outer loading is assumed:

- $|\pi \mathrm{ij}|<0.2-$ no correlation,

- $0.2 \leq|\pi i j|<0.4-$ weak correlation,

- $0.4 \leq|\pi i j|<0.7$-moderate correlation,

- $0.7 \leq \mid$ rij $\mid<0.9$-strong correlation,

- $|\pi \mathrm{i} j| \geq 0.9$-very strong correlation.

The latent variable IIF is very strongly reflected by two indicators: "Gross expenditure on R\&D" (IIF5) and "Political and operational stability" (IIF1).

The latent variable IHF is very strongly reflected by one indicator-"Researchers in R\&D (per million people)" (IHF4) - and strongly reflected by three indicators: "Employment in knowledge-intensive services" (IHF5); "PISA scales in reading, math, and science" (IHF1); and "Research talent in business enterprise" (IHF6).

Two indicators very strongly reflect the latent variable ILF: "GERD performed by business enterprise" (ILF1), and "GERD financed by business enterprise" (ILF2). 
Table 3 Indicators of latent variables qualified for the model

\begin{tabular}{|c|c|c|c|}
\hline Latent variables & Description of indicator & Code & Loadings \\
\hline \multirow[t]{7}{*}{ Institutional factors } & & IIF & \\
\hline & Political and operational stability & IIF1 & 0.843 \\
\hline & Government effectiveness & IIF2 & $0.975($ Omitted)* \\
\hline & Regulatory quality & IIF3 & $0.945($ Omitted)* \\
\hline & Ease of starting a business & IIF4 & 0.479 (Omitted) \\
\hline & Gross expenditure on R\&D (GERD) & IIF5 & 0.889 \\
\hline & Expenditure on education & IIF6 & 0.580 (Omitted) \\
\hline \multirow[t]{7}{*}{ Human factors } & & $\mathrm{HHF}$ & \\
\hline & PISA scales in reading, math, \& science & IHF1 & 0.881 \\
\hline & Graduates in science \& engineering & IHF2 & 0.107 (Omitted) \\
\hline & Tertiary level inbound mobility & IHF3 & 0.536 (Omitted) \\
\hline & Researchers, full time equivalent/million people & IHF4 & 0.930 \\
\hline & Employment in knowledge-intensive services & IHF5 & 0.862 \\
\hline & Research talent in business enterprise & IHF6 & 0.816 \\
\hline \multirow[t]{6}{*}{ Linkage factors } & & ILF & \\
\hline & GERD performed by business enterprise & ILF1 & 0.917 \\
\hline & GERD financed by business enterprise & ILF2 & 0.910 \\
\hline & University-industry research collaboration & ILF3 & $0.920(\text { Omitted })^{*}$ \\
\hline & State of cluster development & ILF4 & $0.918(\text { Omitted })^{*}$ \\
\hline & Joint venture/strategic alliance deals & ILF5 & 0.506 (Omitted) \\
\hline \multirow[t]{8}{*}{ Framework factors } & & IFF & \\
\hline & ICT access & IFF1 & 0.906 \\
\hline & ICT use & IFF2 & 0.951 (Omitted)* \\
\hline & Electricity output, kWh/mn pop & IFF3 & 0.525 (Omitted) \\
\hline & Logistics performance & IFF4 & 0.916 \\
\hline & Gross capital formation & IFF5 & 0.055 (Omitted) \\
\hline & Environmental performance & IFF6 & 0.897 \\
\hline & The rule of law & IFF7 & $0.953($ Omitted)* \\
\hline \multirow[t]{7}{*}{ Output intangible indicators } & & Oll & \\
\hline & Patent applications by origin & Oll1 & 0.923 \\
\hline & PCT international applications by origin & OII2 & 0.941 \\
\hline & Scientific and technical publications & O॥3 & 0.478 (Omitted) \\
\hline & Trademark application class count by origin & O॥4 & 0.357 (Omitted) \\
\hline & Industrial designs by origin & Oll5 & 0.533 (Omitted) \\
\hline & ICTs and business model creation & O॥6 & 0.898 \\
\hline \multirow[t]{6}{*}{ Output tangible indicators } & & OTI & \\
\hline & Cultural and creative services exports & OTI1 & 0.668 (Omitted) \\
\hline & Creative goods exports & OTI2 & 0.446 (Omitted) \\
\hline & The growth rate of GDP per person engaged & OTI3 & 0.517 (Omitted) \\
\hline & High-tech and medium high-tech output & OT/4 & 0.468 (Omitted) \\
\hline & New business density & OTI5 & 0.484 (Omitted) \\
\hline
\end{tabular}

*The indicators that do not meet collinearity criteria

The latent variable IFF is very strongly reflected by two indicators: "Logistics performance" (IFF4) and "ICT access" (IFF1). Also, the latent variable ILF is strongly reflected by one indicator, "Environmental performance" (IFF6). 


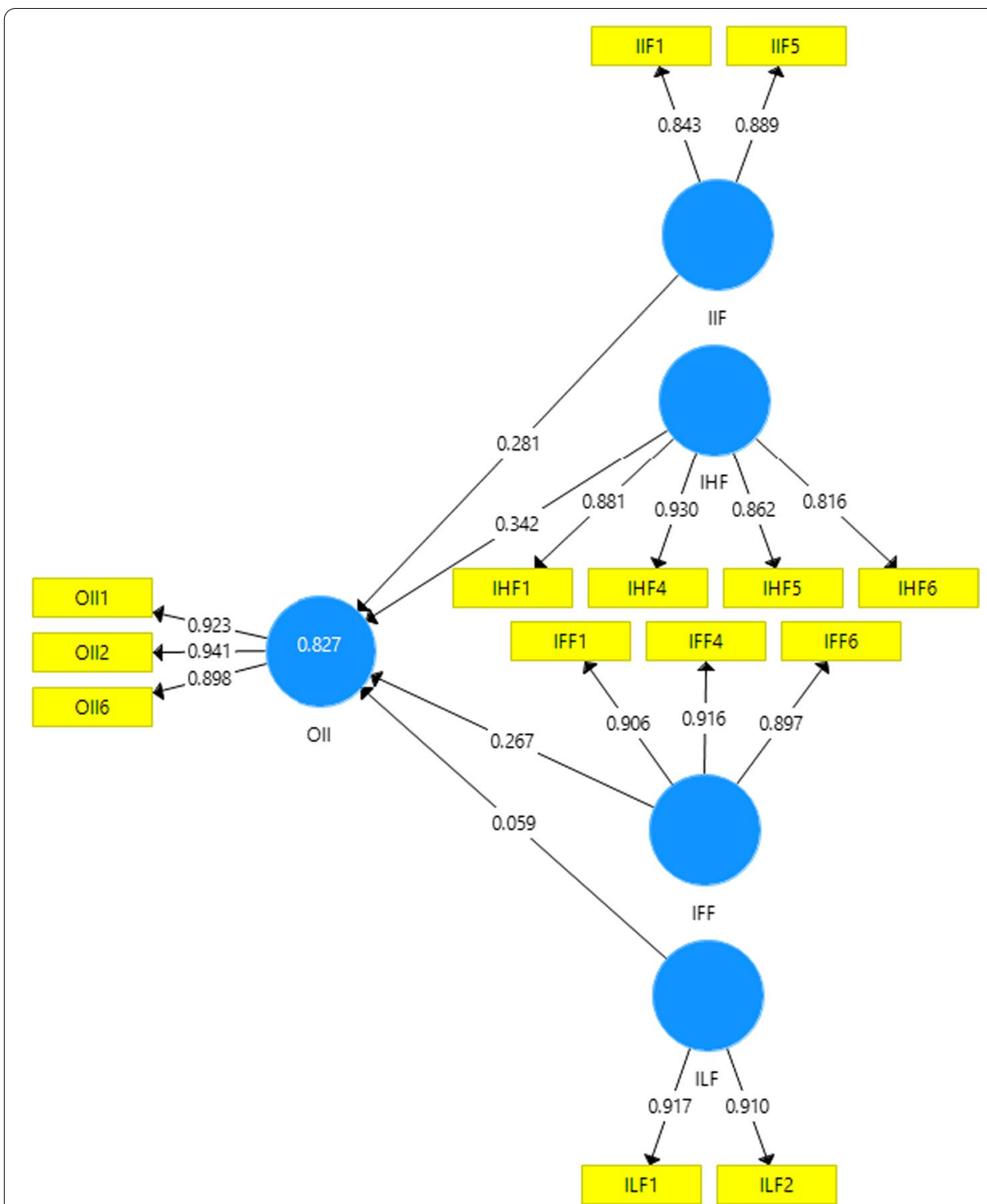

Fig. 2 Results of estimation of PLS-SEM 2015-2018 model

The latent variable OII is very strongly reflected by two indicators: "PCT international applications by origin" (OII2) and "Patent applications by origin" (OII1). Moreover, the latent variable OII is strongly reflected by one indicator- "ICTs and business model creation" (OII6).

The estimation of the internal model parameters indicates a significant positive correlation between UIC predictors and the level of UIC performance in the studied group of 33 European countries in the period 2015-2018. This means that those countries that reported a higher level of development of input factors also had a better UIC performance in the observed period. ${ }^{6}$

$$
\text { OIIt }=0.488 * \mathrm{ILF}_{2015-2018}+3.7695
$$

${ }^{6}$ Parameter $\alpha_{0}$ was estimated in the PLS program (Rogowski, 1990). 
Table 4 Assessing the results of outer models

\begin{tabular}{|c|c|c|c|c|c|}
\hline Latent variables & Indicators & rho_A & $\begin{array}{l}\text { Average Varianc } \\
\text { Extracted (AVE) }\end{array}$ & $\begin{array}{l}\text { eComposite } \\
\text { Reliability }\end{array}$ & Cronbach's Alpha \\
\hline \multirow[t]{2}{*}{ IIF } & $\| F 1$ & 0.681 & 0.750 & 0.857 & 0.669 \\
\hline & IIF5 & & & & \\
\hline \multirow[t]{4}{*}{ IHF } & $\mathrm{HF} 1$ & 0.902 & 0.763 & 0.928 & 0.896 \\
\hline & IHF4 & & & & \\
\hline & IHF5 & & & & \\
\hline & IHF6 & & & & \\
\hline \multirow[t]{2}{*}{ ILF } & ILF1 & 0.803 & 0.834 & 0.910 & 0.802 \\
\hline & ILF2 & & & & \\
\hline \multirow[t]{3}{*}{ IFF } & IFF1 & 0.895 & 0.821 & & \\
\hline & IFF4 & & & & \\
\hline & IFF6 & & & & \\
\hline \multirow[t]{3}{*}{ Oll } & Oll1 & 0.916 & 0.848 & 0.944 & 0.911 \\
\hline & $\mathrm{O} \| 2$ & & & & \\
\hline & Oll6 & & & & \\
\hline
\end{tabular}

*Average Variance Extracted (AVE)

Table 5 Fornell-Larcker criterion analysis for checking discriminant validity

\begin{tabular}{llllll}
\hline & IFF & IHF & IIF & ILF & OII \\
\hline IFF & 0.915 & & & & \\
IHF & 0.920 & 0.863 & & & \\
IIF & 0.940 & 0.942 & 0.900 & & \\
ILF & 0.863 & 0.929 & 0.879 & 0.879 & \\
OII & 0.886 & 0.893 & 0.904 & 0.905 & 0.919 \\
\hline
\end{tabular}

Table 6 Assessing the results of inner models

\begin{tabular}{|c|c|c|c|c|c|}
\hline & Path coefficients & $\begin{array}{l}\text { Standard deviation } \\
\text { (STDEV) }\end{array}$ & $\begin{array}{l}\text { T-statistics }(\mid \mathrm{O} / \\
\text { STDEV|) }\end{array}$ & $P$ values & $R^{2}$ \\
\hline $\mathrm{IFF} \rightarrow \mathrm{OII}$ & 0.191 & 0.256 & 0.749 & 0.454 & 0.827 \\
\hline$\|\mathrm{HF} \rightarrow \mathrm{O}\|$ & -0.156 & 0.238 & 0.657 & 0.512 & \\
\hline$\|\mathrm{F} \rightarrow \mathrm{O}\|$ & 0.407 & 0.224 & 1.818 & 0.070 & \\
\hline$\|\mathrm{LF} \rightarrow \mathrm{O}\|$ & 0.488 & 0.163 & 2.992 & 0.003 & \\
\hline
\end{tabular}

Aside from investigating latent variables correlations, this way of modelling also helps estimate these variables' values (weighted sums of indicators). For that reason, a synthetic measurement, with which we can obtain a linear ordering of the studied objects, is calculated for each of the model's latent variables.

Based on estimated values of the input and output variables, rankings of the studied countries have been compiled: a ranking of input and output variables. The results are shown in Table 8.

The countries are also divided into typological groups, according to similar volumes of UIC inputs and outputs. The results of the grouping are presented in Fig. 4a-e. The 
Table 7 Stone-Geisser test $Q^{2}$ values

\begin{tabular}{ll}
\hline Indicator & $\mathbf{2 0 1 5 - 2 0 1 8}$ \\
\hline Oll1 & 0.516 \\
Oll2 & 0.482 \\
Oll6 & 0.798 \\
General & 0.827 \\
\hline
\end{tabular}

Source: authors' own work

boundaries between the groups have been established based on the arithmetic means and standard deviations of the synthetic measure $z_{\mathrm{i}}$ (equal to 0 and 1 , respectively, for each of the latent variables). The groups are as follows:

- Group I (very high level of latent variable): $\mathrm{zi} \geq 1$,

- Group II (high level of latent variable): $0<\mathrm{zi} \leq 1$,

- Group III (medium and low level of latent variable): $-1<\mathrm{zi} \leq 0$,

- Group IV (very low level of latent variable): $\mathrm{zi} \leq-1$.

\section{Discussion}

A very high level of institutional factor development was observed in the following six countries: Finland, Denmark, Germany, the Netherlands, Austria, and Luxemburg. The group of the countries with a high level of institutional factors development comprised eleven countries: Ireland, United Kingdom, Belgium, Sweden, Spain, Estonia, Czech Republic, France, Lithuania, Malta, and Slovenia. Nine countries were qualified for the group of economies with a medium level of institutional factors development: Slovakia, Poland, Portugal, Cyprus, Latvia, Hungary, Italy, Croatia, and Serbia. Six countries were characterized by low levels of institutional factors development: North Macedonia, Bulgaria, Greece, Romania, Montenegro, and Albania. Finally, Bosnia and Herzegovina is in the bottom place as the country with the lowest level of institutional factors development.

When one considers the human factors, the classification looks somewhat different. Here, the top ranks are occupied by EU member states based on highly developed human capital, focusing on functional literacy, knowledge, and the R\&D sector (Denmark, Finland, the Netherlands, Germany, Belgium, Luxemburg, and Austria). The group with a high level of human capital development comprised 11 countries: France, Ireland, United Kingdom, Sweden, Slovenia, Estonia, Spain, Czech Republic, Hungary, Malta, and Poland. Eight countries were qualified for the group of economies with a medium level of human capital development: Lithuania, Italy, Slovakia, Latvia, Portugal, Croatia, Bulgaria, and Greece.

Countries with weak indicators of functional literacy and of knowledge, and a small percentage of spending on R\&D sectors (Cyprus, Serbia, Montenegro, North Macedonia, Romania, Bosnia and Herzegovina, Albania) are ranked at the bottom. 


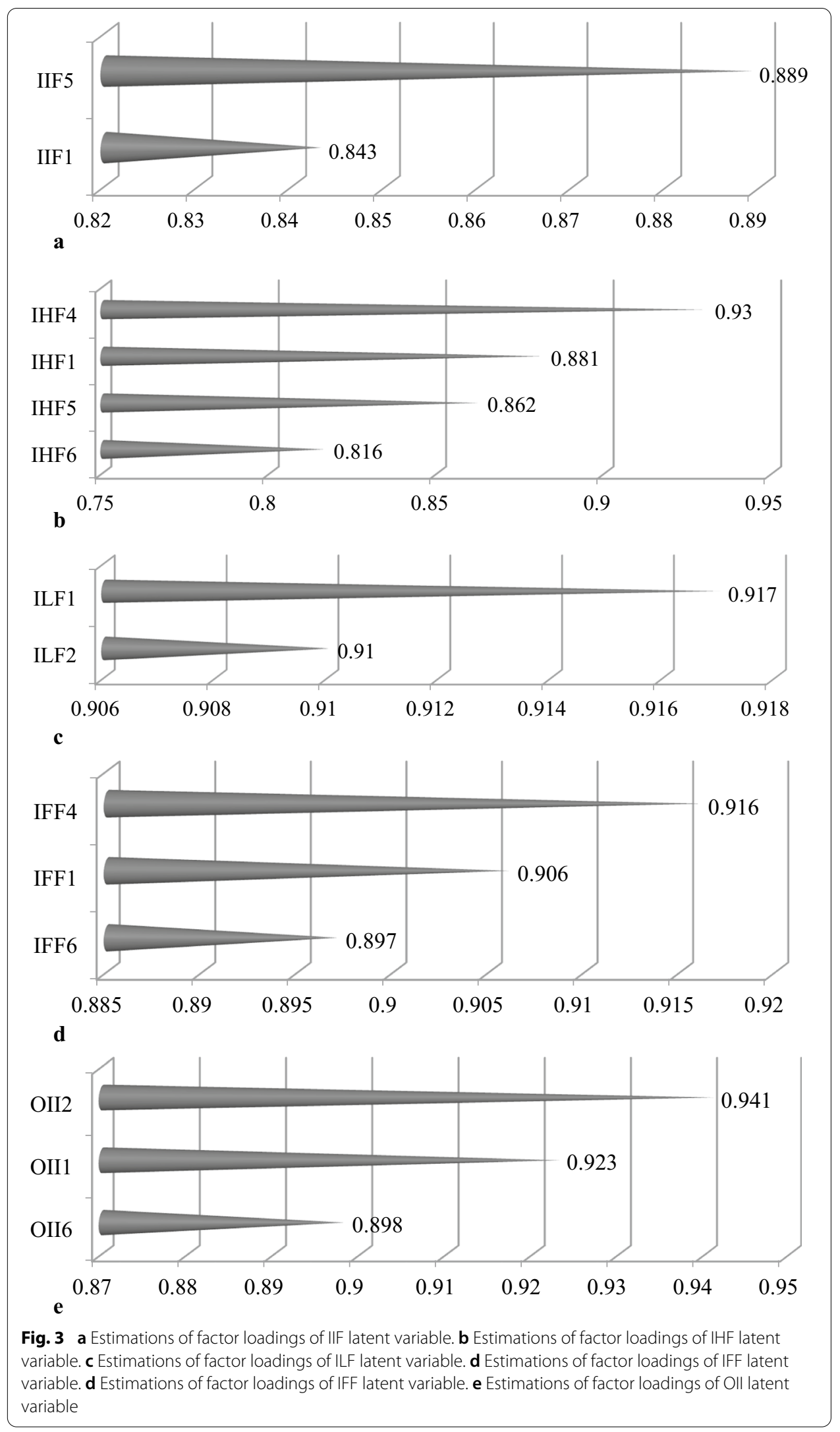


Table 8 Rankings of UIC input and output indicators over the period of three years (2015-2018)

\begin{tabular}{|c|c|c|c|c|c|}
\hline Country & IFF & IHF & IIF & ILF & OII \\
\hline Albania & 32 & 33 & 32 & 33 & 32 \\
\hline Austria & 8 & 7 & 5 & 3 & 8 \\
\hline Belgium & 11 & 5 & 9 & 4 & 12 \\
\hline Bosnia and Herzegovina & 33 & 32 & 33 & 32 & 33 \\
\hline Bulgaria & 27 & 25 & 28 & 23 & 26 \\
\hline Croatia & 26 & 24 & 25 & 26 & 28 \\
\hline Cyprus & 19 & 27 & 21 & 25 & 25 \\
\hline Czech Republic & 15 & 15 & 13 & 16 & 19 \\
\hline Denmark & 2 & 1 & 2 & 6 & 5 \\
\hline Estonia & 14 & 13 & 12 & 17 & 15 \\
\hline Finland & 7 & 2 & 1 & 2 & 1 \\
\hline $\begin{array}{l}\text { France } \\
\text { Germany }\end{array}$ & $\begin{array}{l}6 \\
5\end{array}$ & $\begin{array}{l}8 \\
4\end{array}$ & $\begin{array}{l}14 \\
3\end{array}$ & $\begin{array}{l}9 \\
1\end{array}$ & $\begin{array}{l}7 \\
2\end{array}$ \\
\hline Greece & 24 & 26 & 29 & 31 & 31 \\
\hline Hungary & 25 & 16 & 23 & 18 & 22 \\
\hline Ireland & 10 & 9 & 7 & 8 & 14 \\
\hline Italy & 17 & 20 & 24 & 11 & 16 \\
\hline Latvia & 22 & 22 & 22 & 30 & 24 \\
\hline Lithuania & 18 & 19 & 15 & 24 & 21 \\
\hline Luxemburg & 1 & 6 & 6 & 12 & 3 \\
\hline Malta & 12 & 17 & 16 & 15 & 10 \\
\hline Montenegro & 31 & 29 & 31 & 28 & 29 \\
\hline The Netherlands & 4 & 3 & 4 & 5 & 4 \\
\hline North Macedonia & 30 & 30 & 27 & 22 & 20 \\
\hline Poland & 23 & 18 & 19 & 21 & 18 \\
\hline Portugal & 21 & 23 & 20 & 20 & 17 \\
\hline Romania & 28 & 31 & 30 & 27 & 30 \\
\hline Serbia & 29 & 28 & 26 & 29 & 27 \\
\hline Slovakia & 20 & 21 & 18 & 19 & 23 \\
\hline Slovenia & 16 & 12 & 17 & 14 & 13 \\
\hline Spain & 9 & 14 & 11 & 13 & 11 \\
\hline Sweden & 13 & 11 & 10 & 10 & 6 \\
\hline United Kingdom & 3 & 10 & 8 & 7 & 9 \\
\hline
\end{tabular}

According to institutional factors, the ranking of countries demonstrates a dominance of North and Western European economies and those "catch-up" economies from Central Europe. Economies of Southeastern Europe occupy the lower ranks.

A very high level of developed linkage factors was observed in the following six countries: Finland, Denmark, Germany, the Netherlands, Austria, and Luxemburg. The group with a high level of developed linkage factors comprised 11 countries: Ireland, United Kingdom, Belgium, Sweden, Spain, Estonia, Czech Republic, France, Lithuania, Malta, and Slovenia. Nine countries qualified for the group of economies with a medium level of developed linkage factors: Slovakia, Poland, Portugal, Cyprus, Latvia, Hungary, Italy, Croatia, and Serbia. Six countries were characterized by low levels of developed linkage 


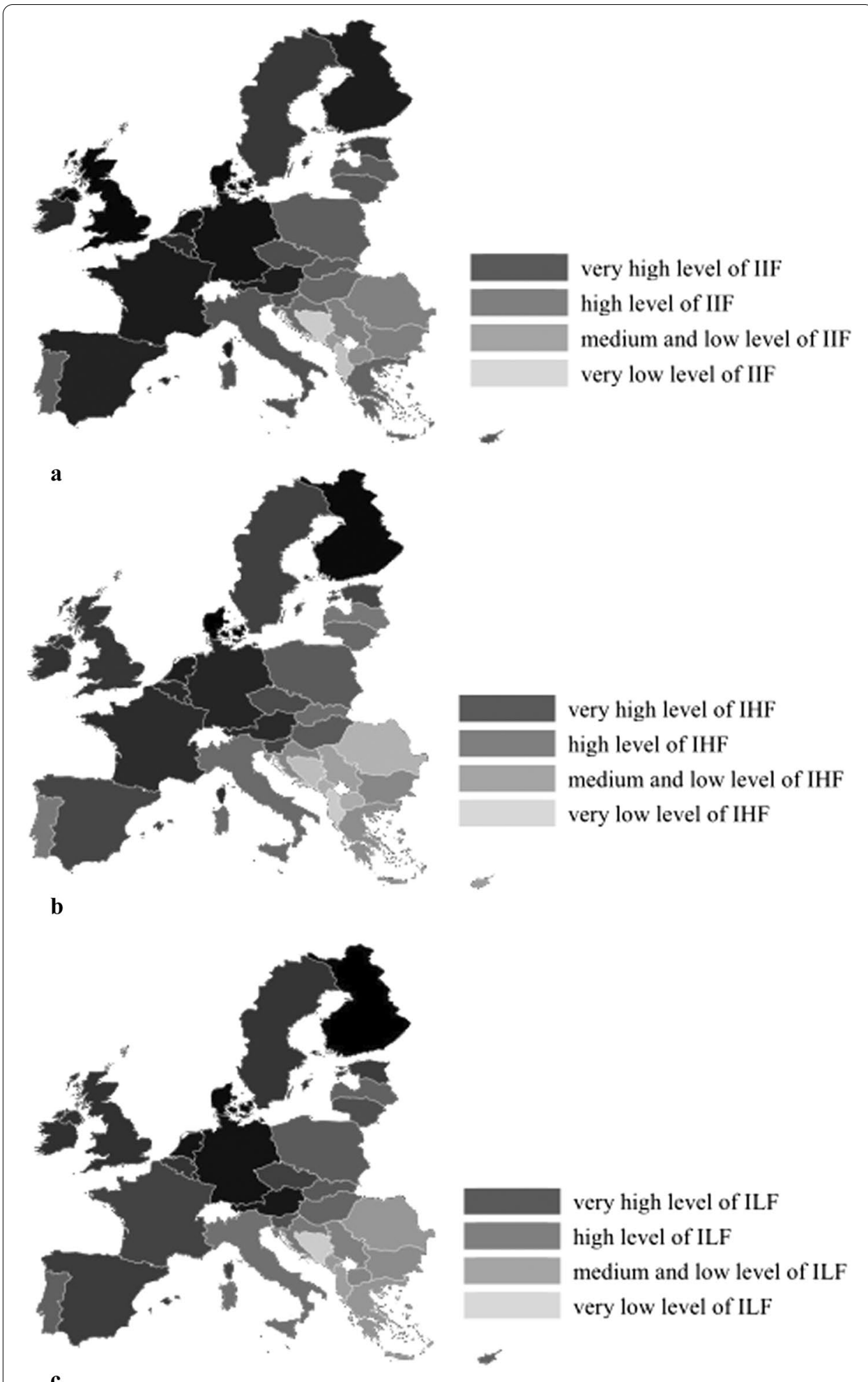

Fig. 4 a Division of EU countries into typological groups according to institutional factors. b Division of EU countries into typological groups according to human factors. c Division of EU countries into typological groups according to linkage factors. $\mathbf{d}$ Division of EU countries into typological groups according to framework factors. e Division of EU countries into typological groups according to intangible output indicators 


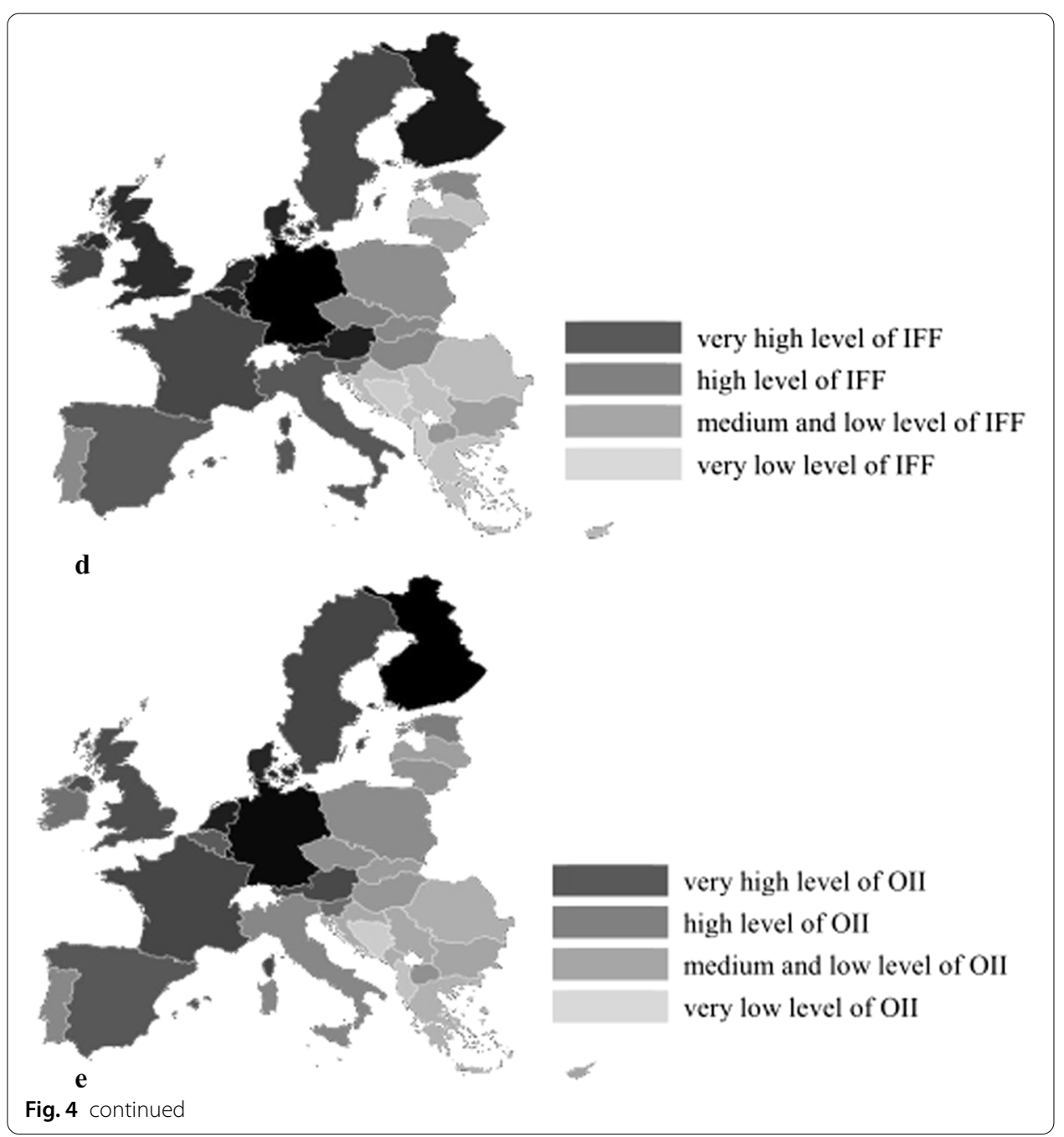

factors: North Macedonia, Bulgaria, Greece, Romania, Montenegro, and Albania. Bosnia and Herzegovina were characterized as the country with very low levels of developed linkage factors.

A very high level of developed framework factors was observed in the following eight countries: Luxemburg, Denmark, United Kingdom, the Netherlands, Germany, France, Finland, and Austria. The group with a high level of developed framework factors comprised six countries: Spain, Ireland, Belgium, Malta, Sweden, and Estonia. Thirteen countries were qualified for the group of economies with a medium level of developed framework factors: Czech Republic, Slovenia, Italy, Lithuania, Cyprus, Slovakia, Portugal, Latvia, Poland, Greece, Hungary, Croatia, and Bulgaria. Four countries were characterized by low levels of developed framework factors: Romania, Serbia, North Macedonia, and Montenegro. Finally, two Balkan countries were characterized by very low levels of developed framework factors: Albania and Bosnia and Herzegovina.

According to framework factors, the countries' ranking demonstrates a dominance of North and Western European economies and those "catch-up" economies from Central Europe. Economies of Southeastern Europe occupy the lower ranks. 
As presented in the analysis of intangible output indicators, the top ranks are occupied by five EU member states based on highly developed human capital, focusing on functional literacy, innovation, ICT use, and the R\&D sector (Finland, Germany, Luxemburg, the Netherlands and Denmark.). The group with a high level of intangible output indicators comprised nine countries: Sweden, France, Austria, United Kingdom, Malta, Spain, Belgium, Slovenia, and Ireland. Fifteen countries qualified for the group of economies with medium and low levels of intangible output indicators: Estonia, Italy, Portugal, Poland, Czech Republic, North Macedonia, Lithuania, Hungary, Slovakia, Latvia, Cyprus, Bulgaria, Serbia, Croatia, and Montenegro. Countries with weak indicators of patent applications by origin, PCT international applications by origin, and ICTs and business model creation (Romania, Greece, Albania and Bosnia and Herzegovina) were ranked at the bottom.

Within the EU-28, most countries treat UIC as a vital source of increasing the performance of companies. Nevertheless, the Balkan countries still lack cooperation between the universities and companies.

\section{Conclusions}

This research presents empirical studies' results of the relationship between UIC predictors and performances in selected European countries. The research involved developing a PLS-SEM model, measurement of the latent variables based on sets of observable variables, and the estimation and verification of the PLS-SME model. The modeling outcomes reveal a significant favorable influence of impact factors on the UIC performance in the analyzed European countries. Based on the literature review, the authors identified four main groups of factors that impact UIC performance. Firstly, there are institutional factors, which refer to the business environment and expenditures on R\&D; secondly, there are human factors, which refer to functional literacy and research; thirdly, there is a linkage factor, which refers to relationships between universities and firms; and fourthly, there are framework factors, which refer to the business infrastructure. Finally, the authors defined the "output factors" that present the level of UIC in a specific country.

On average, predictors of successful UIC are led by EU-15 member states. A very highlevel input indicator was observed in the following seven countries: Denmark, Finland, Germany, the Netherlands, Austria, Luxemburg, and the United Kingdom. The group with a high level of developed input factors comprised nine countries: Belgium, Ireland, France, Sweden, Spain, Estonia, Slovenia, Czech Republic, and Malta. Eleven countries qualified for the group of economies with a medium level of developed input factors: Italy, Poland, Lithuania, Slovakia, Hungary, Portugal, Latvia, Cyprus, Croatia, Bulgaria, and Greece. Six Balkan countries are ranked bottom in Europe, and these are countries with a low level of institutional factors development: North Macedonia, Serbia, Romania, Montenegro, Albania, and Bosnia and Herzegovina.

To improve the economic situation in the region, the Balkan countries should, in the long term, revise their education systems and invest more money in knowledge, networking, and R\&D in general. Based on both public and private initiatives, this investment will have a long-term positive impact on companies' productivity, as well as their profit. Furthermore, they should follow successful examples from the EU member states 
and launch specialized programs for supporting innovation in the short term. The authors suggest Austria and Slovenia as the best model countries for the Balkan region since these two countries have been the best example for the Balkan economies in many fields throughout history. Moreover, universities must be more focused on the companies' real needs in the future if they want to justify their role in society.

This research provides new knowledge on how different factors accelerate UIC in Europe. To the best of the authors' knowledge, it is the first research to investigate links between institutional factors, human capital, linkage factors, and framework factors on the one side, and output factors of UIC on the other by using the PLS-SEM method. Based on the described indicators, the authors improved a UIC model driven by investments in linkage factors.

\begin{abstract}
Abbreviations
AVE: Average variance extracted; CB: Covariance-based; CB-SEM: Covariance-based structural equation modeling; EU: The European Union; G4: USA, Japan, Canada and Western Europe; GDP: Gross domestic product; GERD: Gross domestic expenditure on R\&D; Gll: Global innovation index; HTMT: Heterotrait-monotrait ratio; PCT: Patent cooperation treaty; PLS: Partial least square method; PLS-SEM: Partial least squares structural equation modeling; R\&D: Research and development; SEM: Structural equation modeling method; STDEV: Standard deviation; UIC: Between university-industry collaboration; URS: Universities and research institutes; USA: The United States of America; VIF: Variance inflation factor; WIPO: World Intellectual Property Organization.
\end{abstract}

\title{
Acknowledgements
}

Many thanks to Dr. Iwona Skrodzka for support in creating the PLS-SME method that enabled us to conduct this research.

\section{Authors' contributions}

$B C$ investigated links between institutional factors, human capital, linkage factors, and framework factors on the one side, and output factors of UIC on the other by using the PLS-SEM method. PA provided literature review about the factors impacting university-industry collaboration. DH provided dataset, and worked on technical issues in the paper (copy editing, creation of tables and figures, etc.). All authors read and approved the final manuscript.

\section{Funding}

The article is created within the programme group P6-0372 and supported by Slovenian Research Agency-5442-1/2018/89.

Availability of data and materials

Public data, provided by WIPO, 2015-2018: https://www.wipo.int/edocs/pubdocs/en/wipo_pub_gii_2020.pdf.

\section{Declarations}

Competing interests

Not applicable.

Received: 6 August 2021 Accepted: 24 February 2022

Published online: 08 March 2022

\section{References}

Aiello, F. \& Cardamone, P. \& Pupo, V. (2019). New evidence on the firm-university linkages in Europe. The role of meritocratic management practices. Working Papers 201905, Università della Calabria, Dipartimento di Economia, Statistica e Finanza "Giovanni Anania"-DESF.

Al-Agtash, S., \& Al-Fahoum, F. (2008). An innovative model for university-industry partnership. International Journal of Innovation and Learning, 5(5), 512-532.

Albats, E., Bogers, M., \& Podmetina, D. (2020). Companies' human capital for university partnerships: a micro-foundational perspective. Technological Forecasting and Social Change. https://doi.org/10.1016/j.techfore.2020.120085

Ankrah, S., \& AL-Tabbaa, O. (2015). Universities-industry collaboration: A systematic review. Scandinavian Journal of Management., 31(3), 387-408. https://doi.org/10.1016/j.scaman.2015.02.003

Arvanitis, S., Kubli, U., \& Woerter, M. (2008). University-industry knowledge and technology transfer in Switzerland: What university scientists think about cooperation with private enterprises. Research Policy., 37(10), 1865-1883. https://doi. org/10.1016/j.respol.2008.07.005

Attia, A. M. (2015). National innovation systems in developing countries: Barriers to university-industry collaboration in Egypt. International Journal of Technology Management \& Sustainable Development., 14(2), 113-124. https://doi.org/ 10.1386/tmsd.14.2.113_1 
Banal-Estañol, A. et al. (2011). Research output from university-industry collaborative projects. Working Papers 2011/23, Institut d'Economia de Barcelona (IEB).

Barnes, T., Pashby, I., \& Gibbons, A. (2002). Effective university-industry interaction: A multi-case evaluation of collaborative R\&D projects. European Management Journal., 20(3), 272-285. https://doi.org/10.1016/s0263-2373(02)00044-0

Betz, F., Khalil, F., \& Hosni, Y. (2010). Creating and managing a technology economy (management of technology). World Scientific Publishing Company.

Boardman, C., \& Bozeman, B. (2015). Academic faculty as intellectual property in university-industry research alliances, Economics of Innovation and New Technology., 24(5), 403-420. https://doi.org/10.1080/10438599.2014.988499

Bodas Freitas, I. M., Geuna, A., \& Rossi, F. (2013). Finding the right partners: Institutional and personal modes of governance of university-industry interactions. Research Policy., 42(1), 50-62. https://doi.org/10.1016/j.respol.2012.06.007

Bstieler, L., Hemmert, M., \& Barczak, G. (2017). The changing bases of mutual trust formation in inter-organisational relationships: A dyadic study of university-industry research collaborations. Journal of Business Research., 74, 47-54 https://doi.org/10.1016/j.jbusres.2017.01.006

Chin, W.W. \& Marcolin, B.L. \& Newsted, P.R. (1996). A partial least squares latent variable modelling approach for measuring interaction effects: results from a Monte Carlo simulation study and voice mail emotion/adoption study. Paper presented at the 17th International Conference on Information Systems, Cleveland. https://doi.org/10.1287/isre.14.2.189.16018

Collier, A., Gray, B. J., \& Ahn, M. J. (2011). Enablers and barriers to university and high technology SME partnerships. Small Enterprise Research., 18(1), 2-18. https://doi.org/10.5172/ser.18.1.2

Cornell University, INSEAD, and WIPO (2010-2020) The Global Innovation Index 2020: Who will finance innovation? Ithaca, Fontainebleau, and Geneva.

D'Costa, A.P. (2006). Exports, university-industry linkages, and innovation challenges in Bangalore, India. Policy Research Working Paper Series 3887, The World Bank.

de Medeiros Rocha, M., Brito Alves Lima, G., Lameira, V. D. J., \& Gonçalves Quelhas, O. L. (2012). Innovation as a critical success factor: an exploratory study about the partnership among university with the pharmaceutical industry in Brazil. Journal of Technology Management \& Innovation., 7(3), 148-160. https://doi.org/10.4067/S0718-27242012000300013

Draghici, A. \& Baba, C.F. \& Draghici, G. \& Ivascu, L.V. (2016). The development of an evaluation model for universities and industry collaboration in open innovation. Proceedings of the MakeLearn and TIIM Joint International Conference.

Esposito Vinzi, V., Chin, W. W., Henseler, K., \& Wand, H. (Eds.). (2010). Handbook of partial least squares: Concepts, methods and applications. Springer. ISBN: 978-3-540-32827-8.

Fernandes, C. I., \& Ferreira, J. J. M. (2013). Knowledge spillovers: Cooperation between universities and KIBS. R\&D Management, 43(5), 461-472. https://doi.org/10.1111/radm.12024

Ferru, M. (2010). Formation process and geography of science-industry partnerships: The case of the University of Poitiers. Industry and Innovation., 17(6), 531-549. https://doi.org/10.1080/13662716.2010.509998

Flores, M., Boër, C., Huber, C., Plüss, A., Schoch, R., \& Pouly, M. (2009). Universities as key enablers to develop new collaborative environments for innovation: Successful experiences from Switzerland and India. International Journal of Production Research., 47(17), 4935-4953. https://doi.org/10.1080/00207540902847454

Fornell, C., \& Larcker, D. F. (1981). Evaluating structural equation models with unobservable variables and measurement error. Journal of Marketing Research., 18(1),39-50. https://doi.org/10.1177/002224378101800104

Goel, R., Göktepe-Hulten, D., \& Grimpe, C. (2017). Who instigates university-industry collaborations? University scientists versus firm employees. Small Business Economics., 48, 503-524. https://doi.org/10.1007/s11187-016-9795-9

Guan, J. C., Yam, R. C. M., \& Mok, C. K. (2005). Collaboration between industry and research institutes/universities on industrial innovation in Beijing China. Technology Analysis \& Strategic Management., 17(3), 339-353. https://doi.org/ 10.1080/09537320500211466

Hadjimanolis, A. (2006). A case study of SME-university research collaboration in the context of a small peripheral country (Cyprus). International Journal of Innovation Management., 10(1), 65-88. https://doi.org/10.1142/S136391960 6001405

Hair, J. F., Hult, G. T. M., Ringle, C. M., \& Sarstedt, M. (2017). A primer on partial least squares structural equation modeling PLS-SEM. Sage.

Hair, J. F., Risher, J. J., Sarstedt, M., \& Ringle, C. M. (2019). When to use and how to report the results of PLS-SEM. European Business Review., 31(1), 2-24. https://doi.org/10.1108/EBR-11-2018-0203

Hemmert, M., Bstieler, L., \& Okamuro, H. (2014). Bridging the cultural divide: Trust formation in university-industry research collaborations in the US, Japan, and South Korea. Technovation, 34(10), 605-616. https://doi.org/10.1016/j. technovation.2014.04.006

Henderson, J., McAdam, R., \& Leonard, D. (2006). Reflecting on a TQM-based university/industry partnership: Contributions to research methodology and organisational learning. Management Decision, 44(10), 1422-1440. https://doi. org/10.1108/00251740610715731

Henseler, J., \& Dijkstra, T. K. (2015). ADANCO 2.0. Composite Modeling GmbH \& Co. KG.

Henseler, J., Ringle, C. M., \& Sarstedt, M. (2012). Using partial least squares path modeling in international advertising research: Basic concepts and recent issues. In W. S. Okazaki (Ed.), Handbook of research in international advertising (pp. 252-276). Edward Elgar.

Hillebrand, B., \& Biemans, W. G. (2003). The relationship between internal and external cooperation. Journal of Business Research, 56(9), 735-743. https://doi.org/10.1016/s0148-2963(01)00258-2

Hong, J., Heikkinen, J., \& Blomqvist, K. (2010). Culture and knowledge co-creation in R\&D collaboration between MNCs and Chinese universities. Knowledge and Process Management, 17(2), 62-73. https://doi.org/10.1002/kpm.342

Hulland, J. (1999). Use of Partial Least Squares (PLS) in strategic management research: A Review of Four Recent Studies. Strategic Management Journal., 20(2), 195-204. https://doi.org/10.1002/(SICI)1097-0266(199902)20:2\%3c195::AIDSMJ13\%3e3.0.CO;2-7

Hwang, I. (2020). The effect of collaborative innovation on ICT-based technological convergence: A patent-based analysis. PLOS ONE, 15(2), 1-20. https://doi.org/10.1371/journal.pone.0228616 
Jöreskog, K. G., \& Wold, H. (1982). The ML and PLS techniques for modeling with latent variables: Historical and comparative aspects. In K. G. Jöreskog \& H. Wold (Eds.), Systems under indirect observations: Causality, structure, prediction (Vol. 1, pp. 263-270). North-Holland.

Kock, N. (2020). WarpPLS user manual: Version 70. ScriptWarp Systems.

Koschatzky, K. \& Stahlecker, T. (2010). The changing role of universities in the German research system: engagement in regional networks, clusters and beyond. Working Papers Firms and Region. R2/2010, Fraunhofer Institute for Systems and Innovation Research (ISI).

Kozlinska, I. (2012). Obstacles to university-industry cooperation in the domain of entrepreneurship. Journal of Business Management., 6(1), 153-160.

Lai, I., \& Lu, T.-W. (2016). How to improve the university-industry collaboration in Taiwan's animation industry? Academic vs industrial perspectives. Technology Analysis \& Strategic Management., 28(6), 717-732. https://doi.org/10.1080/ 09537325.2016 .1141404

Lata, R., Proff, S., \& Brenner, T. (2018). The influence of distance types on co-patenting and co-publishing in the USA and Europe over time. The Annals of Regional Science, 61(1), 49-71. https://doi.org/10.1007/s00168-017-0857-y

Lee, K.-J. (2011). From interpersonal networks to inter-organisational alliances for university-industry collaborations in Japan: The case of the Tokyo Institute of Technology. R\&D Management., 41(2), 190-201. https://doi.org/10.1111/j. 1467-9310.2011.00633.x

Marotta, D. \& Mark, M. \& Blom, A. \& Thorn, K (2007). Human capital and university-industry linkages' role in fostering firm innovation: an empirical study of Chile and Colombia. Policy Research Working Paper Series 4443.

Merritt, H. (2015). The role of human capital in university-business cooperation: the case of Mexico. Journal of the Knowledge Economy., 6(3), 568-588.

Miguelez, E. et al. (2019). Tied in: The Global Network of Local Innovation. Cahiers du GREThA (2007-2019), Groupe de Recherche en Economie Théorique et Appliquée (GREThA).

MingJi, J., \& Ping, Z. (2014). Research on the patent innovation performance of university-industry collaboration based on complex network analysis. Journal of Business-to-Business Marketing., 21(2), 65-83. https://doi.org/10.1080/10517 $12 x .2014 .903454$

Morisson, A., \& Pattinson, M. (2020). University-industry collaboration. Interreg Europe Policy Learning Platform.

Muscio, A., \&Vallanti, G. (2014). Perceived obstacles to university-industry collaboration: Results from a qualitative survey of Italian academic departments. Industry and Innovation., 21(5), 410-429. https://doi.org/10.1080/13662716.2014. 969935

Myoken, Y. (2013). The role of geographical proximity in university and industry collaboration: case study of Japanese companies in the UK. International Journal of Technology Transfer and Commercialisation (ITTC). https://doi.org/10. 1504/ijttc.2013.064170

Newberg, J. A., \& Dunn, R. L. (2002). Keeping secrets in the campus lab: Law, values and rules of engagement for industry-university R\&D partnerships. American Business Law Journal., 39(2), 187-240. https://doi.org/10.1111/j.1744-1714. 2002.tb00298.x

Nishimura, J. \& Okamuro, H. (2010). R\&D Productivity and the organization of cluster policy: an empirical evaluation of the industrial cluster project in Japan. DRUID Working Papers 10-06, DRUID, Copenhagen Business School, Department of Industrial Economics and Strategy/Aalborg University, Department of Business Studies.

Parkhe, A. (1993). Strategic alliance structuring: A game theoretic and transaction cost examination of interfirm cooperation. The Academy of Management Journal., 36(4), 794-829. https://doi.org/10.2307/256759

Philbin, S. P. (2010). Developing and managing university-industry research collaborations through a process methodology/industrial sector approach. Journal of Research Administration., 41(3), 51-68.

Piva, E., \& Rossi-Lamastra, C. (2013). Systems of indicators to evaluate the performance of university-industry alliances: A review of the literature and directions for future research. Measuring Business Excellence., 178(3), 40-54. https://doi. org/10.1108/mbe-01-2013-0004

Rampersad, G. C. (2015). Developing university-business cooperation through work-integrated learning. International Journal of Technology Management (IJTM)., 68(3/4), 203-227. https://doi.org/10.1504/ijtm.2015.069664

Ringle, C.M.; Wende, S.; Becker, J.M. Smar tPLS, SmartPLS GmbH, Boenningstedt, 2015.

Rogowski, J. Modele miękkie. Teoria i zastosowanie w badaniach ekonomicznych [Soft models. Theory and application in economic studies], Wydawnictwo Filii UW w Białymstoku, 1990.

Ryan, L. (2009). Exploring the growing phenomenon of university-corporate education partnerships. Management Decision., 47(8), 1313-1322. https://doi.org/10.1108/00251740910984569

Rybnicek, R., \& Königsgruber, R. (2019). What makes industry-university collaboration succeeds? A systematic review of the literature. Journal of Business Economics., 89(2), 221-250. https://doi.org/10.1007/s11573-018-0916-6

Salimi, N., \& Rezaei, J. (2016). Measuring efficiency of university-industry PhD projects using best worst method. Scientometrics, 109(3), 1911-1938.

Schein, E. H. (2004). Organisational culture and leadership (3rd ed.). Jossey-Bass.

Schofield, T. (2013). Critical success factors for knowledge transfer collaborations between university and industry. The Journal of Research Administration., 44, 38-56.

Şerbănică, C. (2011). A cause and effect analysis of university: Business cooperation for regional innovation in Romania. Theoretical and Applied Economics., 10(563), 29-44.

Silva, D., Lucas, L., \& Vonortas, N. (2019). Internal barriers to innovation and university-industry cooperation among technology-based SMEs in Brazil. Industry and Innovation, 27(3), 235-263. https://doi.org/10.1080/13662716.2019. 1576507

Sohal, A. S. (2013). Developing competencies of supply chain professionals in Australia: Collaboration between businesses, universities and industry associations. Supply Chain Management, 18(4), 429-439. https://doi.org/10.1108/ scm-07-2012-0228

Valentin, F., \& Jensen, R. (2007). Effects on academia-industry collaboration of extending university property rights. The Journal of Technology Transfer., 32(3), 251-276. 
Vea, R.B. (2014). Industry-academe collaboration for research and development. Discussion Papers DP 2014-10, Philippine Institute for Development Studies.

Wold, H. (1980a). Model construction and evaluation when theoretical knowledge is scarce. In W. J. Kmenta \& J. B. Ramsey (Eds.), Evaluation of econometric models (pp. 47-74). Academic Press.

Wold, H. (1980b). Soft modelling: intermediate between traditional model building and data analysis. Banach Centre Publication. https://doi.org/10.4064/-6-1-333-346

Wold, H. (1982). Soft modeling: The basic design and some extensions. In K. G. Joreskog \& H. O. A. Wold (Eds.), Systems under indirect observations: Part II (pp. 1-54). North-Holland.

Wu, H. (2017). The essentiality of sustainability and variety for industry collaborations with university partners. International Journal of Advanced Corporate Learning., 10(2), 19-29. https://doi.org/10.3991/ijac.v10i2.7272

Xia, G., Xi, G., \& Jiancheng, G. (2014). An analysis of the patenting activities and collaboration among industryuniversity-research institutes in the Chinese ICT sector. Scientometrics, 98(1), 247-263. https://doi.org/10.1007/ s11192-013-1048-y

\section{Publisher's Note}

Springer Nature remains neutral with regard to jurisdictional claims in published maps and institutional affiliations.

Submit your manuscript to a SpringerOpen ${ }^{\circ}$ journal and benefit from:

- Convenient online submission

- Rigorous peer review

- Open access: articles freely available online

- High visibility within the field

- Retaining the copyright to your article

Submit your next manuscript at $\gg$ springeropen.com 